\title{
Mekanisme Pasar Dalam Konteks Idealita Dan Realita \\ (Analisis Pemikiran Abu Yusuf dan Ibn Khaldun)
}

\author{
Nurdania \\ Pasca Sarjana Institut Agama Islam Negeri (IAIN) Parepare \\ nurdania_nasir@yahoo.com
}

\begin{abstract}
Abstrak
Tulisan ini akan membahas sistem harga dalam mekanisme pasar Islami yang ditinjau dari pemikiran Abu Yusuf dan Ibn Khaldun. Pemikiran keduanya merupakan khasanah intelektual yang pastinya akan membantu kita dalam menemukan gagasan-gagasan idealis, serta dapat dijadikan sumber pemikiran ekonomi Islam kontemporer. Pemikiran Abu Yusuf dan Ibn Khaldun terkait dengan mekanisme pasar Islami telah menambah wawasan ekonomi Islam pada jangkauan yang lebih luas terhadap konseptualisasi dan aplikasinya. Ditinjau dari konteks idealita, sistem harga dalam mekanisme pasar Islam dapat memberikan harga yang adil bagi produsen dan konsumen, asalkan mekanisme pasar terjadi dengan sempurna. Hal tersebut dapat dijadikan sebagai koreksi solutif atas realita dimana sistem harga dalam mekanisme pasar masa kini, masih banyak terjadi kecurangan dan ketidakadilan.
\end{abstract}

Kata Kunci: Harga, Mekanisme Pasar dan Abu Yusuf

\section{Pendahuluan}

Ekonomi adalah salah satu aspek kehidupan, sedangkan Islam adalah agama yang sempurna. Sebagai agama yang sempurna mustahil Islam tidak dilengkapi dengan sistem dan konsep ekonomi, karena itu permasalahan ekonomi tentu juga sudah diatur di dalam Islam. Dalam Islam, ekonomi bertujuan untuk membawa kepada konsep al-falah (kejayaan) ${ }^{1}$ di dunia dan di akhirat, selain itu ekonomi Islam juga menempatkan manusia sebagai khalifah di muka bumi ini, semua bahan-bahan yang ada di langit dan di bumi 
telah diperuntukkan untuk manusia. ${ }^{2} \mathrm{Hal}$ ini yang membedakan sistem ekonomi Islam dengan sistem ekonomi lainnya, karena di dalam sistem ekonomi selain Islam bertujuan hanya untuk kepuasan dan kejayaan di dunia saja.

Islam merupakan agama penyempurna dari agama-agama sebelumnya dan syari'atnya mengatur seluruh aspek kehidupan, baik yang bersifat aqidah maupun muamalah. Dalam kaidah tentang muamalah, Islam mengatur segala bentuk perilaku manusia dalam berhubungan dengan sesamanya untuk memenuhi kebutuhan hidupnya di dunia. Termasuk di dalamnya adalah kaidah Islam yang mengatur tentang pasar dan mekanismenya.

Pasar adalah tempat dimana antara penjual dan pembeli bertemu dan melakukan transaksi jual beli barang dan atau jasa. Pentingnya pasar dalam Islam tidak terlepas dari fungsi pasar sebagai wadah bagi berlangsungnya kegiatan jual beli. Jual beli sendiri memiliki fungsi penting, mengingat jual beli merupakan salah satu aktifitas perekonomian yang "terakreditasi" dalam Islam. Attensi Islam terhadap jual beli sebagai salah satu sendi perekonomian dapat dilihat dalam surat Al Baqarah ayat 275 bahwa Allah menghalalkan jual beli dan mengharamkan riba. Firman Allah dalam Q.S. Al-Baqarah : 275.

Terjemah:

"Orang-orang yang makan (mengambil) riba tidak dapat berdiri melainkan seperti berdirinya orang yang kemasukan syaitan lantaran (tekanan) penyakit gila. Keadaan mereka yang demikian itu, adalah disebabkan mereka berkata (berpendapat), sesungguhnya jual beli itu sama dengan riba, padahal Allah telah menghalalkan jual beli dan mengharamkan riba. Orang-orang yang telah sampai kepadanya larangan dari Tuhannya, lalu terus berhenti (dari mengambil riba), maka baginya apa yang telah diambilnya dahulu (sebelum datang larangan); dan urusannya (terserah) kepada Allah. Orang yang kembali (mengambil riba), maka orang itu adalah penghuni-penghuni neraka; mereka kekal di dalamnya".

h. 7

2 Ascarya, Akad dan Produk Bank Syariah (Jakarta: PT RajaGrafindo Persada, 2008), 
Dalam sistem Ekonomi Islam, mekanisme pasar dibangun atas dasar kebebasan, yakni kebebasan individu untuk melakukan transaksi barang dan jasa. Namun, kebebasan itu diikat dengan aturan, yaitu tidak melakukan kegiatan ekonomi yang bertentangan dengan aturan syariat, yang antara lain terkait dengan pembentukan harga dan terjadinya transaksi di pasar. Tulisan ini akan membahas sistem harga dalam mekanisme pasar Islami yang ditinjau dari pemikiran Abu Yusuf dan Ibn Khaldun. Pemikiran keduanya merupakan khasanah intelektual yang pastinya akan membantu kita dalam menemukan gagasan-gagasan idealis, serta dapat dijadikan sumber pemikiran ekonomi Islam kontemporer. Pemikiran Abu Yusuf dan Ibn Khaldun terkait dengan mekanisme pasar Islami telah menambah wawasan ekonomi Islam pada jangkauan yang lebih luas terhadap konseptualisasi dan aplikasinya. Ditinjau dari konteks idealita, sistem harga dalam mekanisme pasar Islam dapat memberikan harga yang adil bagi produsen dan konsumen, asalkan mekanisme pasar terjadi dengan sempurna. Hal tersebut dapat dijadikan sebagai koreksi solutif atas realita dimana sistem harga dalam mekanisme pasar masa kini, masih banyak terjadi kecurangan dan ketidakadilan.

\section{Sistem Harga Dalam Mekanisme Pasar Menurut Abu Yusuf}

Nama lengkapnya Ya'qub bin Ibrahim bin Habib bin Khunais bin Sa'ad Al Anshari Al-Jalbi Al-Kufi Al-Baghdadi, lahir di Kufah pada Tahun 113 H (731 M) dan meninggal dunia di Baghdad pada tahun 182 H (798 M). Abu Yusuf menimba berbagai ilmu kepada banyak ulama besar, salah satu gurunya adalah Abu Hanifa. Berkat bimbingan para gurunya serta ditunjang oleh ketekunan dan kecerdasannya, Abu Yusuf Tumbuh sebagai seorang alim yang sangat dihormati oleh berbagai kalangan. Disisi lain, sebagai salah satu bentuk pengakuan dan pengormatan pemerintah atas keluasan dan kedalaman ilmunya, Khalifah Dinasti Abbasiyah, Harun ar-Rasyid, mengangkat Abu Yusuf sebagai ketua Mahkamah Agung (Qadhi Al-qudhah). 
Sekalipun disibukkan dengan berbagai aktifitas mengajar dan birokrasi, Abu Yusuf masih meluangkan waktu untuk menulis. Beberapa karya tulisnya yang terpenting adalah: al-jawami', ar-Radd'ala Siyar al-Auza'i, al-Atsar, Ikhtilaf Abi Hanifah wa Ibn Abi Laila, Adab al-Qadhi, dan al-Kharaj. ${ }^{3}$

Salah satu pemikiran ekonomi Abu Yusuf yang bisa dikatakan kontroversial adalah adanya pendapat yang sepertinya menyangkal terhadap pendapat umum mengenai hubungan terbalik antara persediaan barang (Supply) dan harga, karena menurut Abu Yusuf kenyataan yang terjadi menunjukkan bahwasanya harga tidak bergantung pada permintaan saja, tetapi juga tergantung pada kekuatan penawaran (Demand). Dalam hukum penawaran menyatakan bahwa hubungan antara harga dengan banyaknya komoditi yang ditawarkan mempunyai kemiringan positif. ${ }^{4}$ Formulasi sederhana antara harga dengan jumlah komoditi adalah sebagai berikut:

$$
\mathbf{S}=\mathbf{Q}=\int\left(\mathbf{P}^{+}\right)
$$

Formulasi tersebut menunjukkan bahwa pengaruh harga terhadap jumlah permintaan suatu komoditi adalah positif, apabila $\mathrm{P} \uparrow$ maka $\mathrm{Q} \uparrow$ sebaliknya apabila $\mathrm{P} \downarrow$ maka $Q \downarrow$ Dari formulasi ini dapat disimpulkan bahwasanya hukum penawaran menunjukkan apabila harga komoditi naik, maka akan diikuti penambahan jumlah komoditi yang ditawarkan. Sebaliknya apabila harga komoditi turun, maka akan diikuti penurunan jumlah komoditi yang ditawarkan.

Abu Yusuf menyatakan bahwa tidak ada batasan tertentu tentang murah dan mahalnya harga dipasar. Murah bukan karena melimpahnya makanan, demikian juga mahal bukan karena kelangkaan makanan, kadang makanan sangat sedikit tetapi harganya murah. Murah dan mahal merupakan ketentuan Allah. ${ }^{5}$

${ }^{3}$ Adiwarman Karim, Sejarah Pemikiran Ekonomi Islam, (Jakarta: Rajawali Pers, 2016), h.231-232

${ }^{4}$ Adiwarman Karim, Sejarah Pemikiran Ekonomi Islam, h.252

5 Muhammad, Ekonomi Mikro dalam Perspektif Islam, (Yogyakarta: BPFE, 2004) h.352-353 
Abu Yusuf mengindikasikan ada variabel-variabel tertentu yang juga mempengaruhi terbentuknya harga, misalnya jumlah uang beredar, penimbunan barang, dan lain sebagainya.

\section{Sistem Harga Dalam Mekanisme Pasar Menurut Ibn Khaldun}

Nama lengkap Ibn Khaldun adalah Abdurrahman Abu Zaid Waliuddin Ibn Khaldun, lahir di Tunisia pada awal Ramadhan $732 \mathrm{H}$ atau bertepatan dengan 27 Mei 1332 M. Ibn Khaldun mengawali pelajarannya dari ayahnya sendiri, setelah itu ia pergi berguru kepada para ulama terkemuka, seperti Abu Abdillah Muhammad bin al-Arabi Al-hashayiri, Abu al-Abbas Ahmad ibn Al-Qushshar, Abu Abdillah Muhammad Al-Jiyani, dan Abu Abdillah Muhammad ibn Ibrahim Al-Abili. ${ }^{6}$

Sebagai anggota keluarga aristokrat, Ibn Khaldun sudah ditakdirkan untuk menduduki jabatan tetinggi dalam administrasi negara dan mengambil bagian alam hampir semua pertikaian politik di Afrika Utara. Dari tahun 1375 M sampai 1378 M, ia menjalani pensiunnya di Gal'at Ibn Salamah, sebuah puri di provinsi Oran. Sisa hidupnya dihabiskan di kairo hingga ia wafat pada tanggal 17 Maret 1406 M. Adapun karya terbesar Ibn Khaldun adalah Al-Ibar (Sejarah Dunia).

Pemikiran ekonomi Ibn Khaldun terkait tentang teori harga mengindikasikan bahwa ketika barang-barang kebutuhan ketersediannya sedikit, maka harga akan naik. Namun, jika terjadi impor barang kebutuhan tersebut, sehingga ketersediannya melimpah maka harga akan turun, atau dengan kata lain bagi Ibn Khaldun harga adalah hasil dari hukum permintaan dan penawaran. Menurut Ibn Khaldun, Harga suatu produk terdiri dari tiga unsur yaitu: Gaji, laba, dan pajak. Setiap unsur ini merupakan imbal jasa bagi setiap kelompok dalam masyarakat. ${ }^{7}$ Bila gaji terlalu rendah, pasar akan lesu

\footnotetext{
${ }^{6}$ Adiwarman Karim, Sejarah Pemikiran Ekonomi Islam, (Jakarta: Rajawali Pers, 2016), h.391-392

${ }^{7}$ Adiwarman Karim, Sejarah Pemikiran Ekonomi Islam, (Jakarta: Rajawali Pers, 2016), h.403
} 
dan produksi tidak mengalami peningkatan, sebaliknya jika gaji terlalu tinggi akan terjadi tekanan inflasi dan produsen kehilangan minat untuk bekerja. Jika laba sangat rendah, pedagang terpaksa melikuidasi saham-sahamnya dan tidak dapat memperbaruinya karena tidak ada modal, sebaliknya jika laba terlalu tinggi, para pedagang juga akan melikuidasi saham-sahamnya dan tidak dapat memperbaruinya karena tekanan inflasi. Jika pajak terlalu rendah, pemerintah tidak dapat menjalani fungsinya, sebaliknya jika pajak terlalu tinggi, tekanan fiskal menjadi terlalu kuat sehingga laba para pedagang dan produsen menurun dan hilanglah insentif mereka untuk bekerja. Kondisi-kondisi tersebut, tentu saja akan mempengaruhi ketersediaan barang di pasaran dan otomatis akan mempengaruh sistem harga yang terjadi di pasar.

Hasil pemikiran Abu Yusuf dan Ibn Khaldun mengindikasikan bahwasanya Islam memberikan kebebasan dalam penentuan harga. Pasar adalah penentu harga, artinya pihak manapun tidak boleh mengintervensi harga di pasar. Semua itu bergantung pada kekuatan permintaan dan kekuatan pasar. ${ }^{8}$

Dalam konsep Islam, pertemuan permintaan dan penawaran tersebut haruslah terjadi secara sukarela. Intervensi harga hanya akan menimbulkan excess demand atau excess supply dan selanjutnya menimbulkan pasar gelap. Pasar gelap inilah yang menjadi potensi timbulnya kolusi dan korupsi. ${ }^{9}$

Perhatikan kurva dibawah ini :



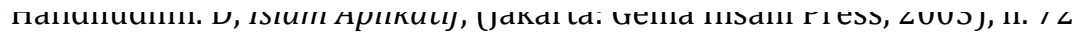




\section{Penjelasan kurva :}

1. Ketika pemerintah menetapkan floor price sebesar $\mathrm{P}^{*}$, sementara harga keseimbangan adalah $\mathrm{P}$, maka akan mengakibatkan kelebihan penawaran (excess supply) sehingga kondisi tersebut menimbulkan kerugian bagi pihak penjual.

2. Ketika pemerintah menetapkan ceilling price sebesar $\mathrm{P}^{*}$, sementara harga keseimbangan adalah $\mathrm{P}$, maka akan mengakibatkan kelebihan permintaan (excess demand) dan hal tersebut memberikan kerugian bagi pembeli.

Namun Islam juga tidak menutup kemungkinan adanya kebijakan penetapan harga dengan syarat dalam kondisi-kondisi tertentu saja dengan tetap berpegang teguh pada nilai-nilai keadilan. Menurut Mannan dalam bukunya The Behavior of Film and Its Objectives in An Islamic Framework, regulasi harga ini harus menunjukkan tiga fungsi dasar, yaitu: ${ }^{10}$

1. Fungsi ekonomi yang berhubungan dengan peningkatan produktivitas dan peningkatan pendapatan masyarakat miskin melalui alokasi dan realokasi sumber daya ekonomi.

2. Fungsi sosial dalam memelihara keseimbangan sosial antara masyarakat kaya dan miskin.

3. Fungsi moral dalam menegakkan nilai-nilai syariah Islam, khususnya yang berkaitan dalam transaksi ekonomi.

Jika pedagang menahan suatu barang, sedangkan pembeli membutuhkannya dengan maksud agar pembeli mau membelinya dengan harga di atas harga pasar. Dalam kasus ini, para pedagang secara suka rela harus menerima penetapan harga oleh pemerintah. Dengan demikian, h.335

10 Munrokhim Misanan, dkk., Ekonomi Islam, (Jakarta: Rajagrafindo Persada, 2009), 
penetapan harga wajib dilakukan agar pedagang menjual harga yang sesuai demi tegaknya keadilan. ${ }^{11}$

\section{Sistem Harga Dalam Mekanisme Pasar Islam}

Pada dasarnya secara idealnya Islam menganut sistem ekonomi pasar bebas, dimana tingkat harga diserahkan pada kekuatan penawaran dan permintaan. Apabila pasar dalam keadaan berjalan secara alami, tidak dibenarkan adanya campur tangan atau intervensi dari manapun termasuk pemerintah terhadap mekanisme pasar dalam hal ini adalah penentuan harga. Akan tetapi, jika harga di pasar tidak lagi ditentukan oleh kekuatan pasar tetapi disebabkan oleh adanya distorsi, seperti penimbunan, kelangkaan, ataupun bencana alam maka dalam kondisi seperti ini maka pemerintah wajib ikut campur dalam mekanisme pasar terkait dengan regulasi penentuan harga. Intervensi pasar juga menjadi penting dalam menjamin ketersediaan barang kebutuhan masyarakat. Pemerintah perlu mengadakan operasi pasar, untuk mengetahui keadaan yang terjadi dipasar sehingga jika terjadi distorsi, pemerintah bisa segera mengambil langkah yang tepat untuk menjamin adanya kestabilan harga dalam mekanisme pasar yang tidak alami.

Dalam konsep ekonomi Islam penentuan harga dilakukan oleh kekuatan-kekuatan pasar. yaitu kekuatan permintaan dan kekuatan penawaran. Dalam konsep Islam. pertemuan permintaan dengan penawaran tersebut haruslah terjadi secara rela sama rela. tidak ada pihak yang merasa terpaksa untuk melakukan transaksi pada tingkat harga tersebut. Sesui dengan firman Allah SWT dalam Quran Surah Annisa ayat 29 (QS 4:29) yang artinya:

Allah berfirman. "Hai orang-orang yang beriman, janganlah kamu saling memakan harta sesamamu dengan jalan yang batil, kecuali dengan jalan perniagaan yang berlaku dengan suka sama suka di antara kamu. Dan

\section{8}

11 Yusuf Qardhawi, Norma dan Etika Ekonomi Islam, (Jakarta: Gema Insani, 1997), h. 
janganlah kamu membunuh dirimu; Sesungguhnya Allah adalah Maha Penyayang kepadamu"

Jadi titik pertemuan antara permintaan dan penawaran yang membentuk harga keseimbangan hendaknya berada dalam keadaan rela sama rela dan tanpa ada paksaan dari salah satu pihak. Islam sangat menjunjung tinggi mekanisme pasar yang berdasarkan atas kekuatan permintaan dan penawaran, dimana titik keseimbangan pasar akan terjadi ketika permintaan bertemu dengan penawaran secara bebas ('antaradhin minkum), Jika proses mencapai titik keseimbangan ini terganggu maka pemerintah harus melakukan intervensi. Hal tersebut tergambar dalam kurva dibawah ini :



Penetapan harga yang tidak adil apabila penetapan harga itu mengandung kezaliman terhadap masyarakat dengan memaksa mereka tanpa hak untuk menjual barang dagangannya dengan harga yang tidak disukainya, atau melarang mereka terhadap apa yang dibolehkan Allah terhadap mereka, semua itu adalah haram. Keadaan ini terjadi ketika naiknya harga akibat kompetisi kekuatan pasar yang bebas yang diakibatkan oleh kekurangan supply dan naiknya permintaan. Ketika masyarakat menjual 
barang dagangannya dengan harga yang normal tanpa menggunakan caracara yang tidak adil, harga naik karena sedikitnya barang atau karena tingginya permintaan. Keadaan ini adalah kehendak Allah. Memaksa pedagang dalam keadaan seperti ini untuk menjual barang dagangan mereka dengan harga tertentu adalah pemaksaan tanpa hak. ${ }^{12}$

Penetapan harga yang dibolehkan bahkan diwajibkan adalah penetapan harga ketika terjadi kenaikan harga yang sangat tinggi yang disebabkan oleh ulah spekulan. Pada saat ketidaksempurnaan pasar karena kezaliman, seperti iktikar, pemerintah dapat memaksa muhtakir untuk menjual barang-barangnya Pada harga yang adil karena penduduk membutuhkannya. Jika para pedagang menjual barang dagangan mereka dengan harga yang lebih mahal dari pada harga yang normal (al-ma'ruf) sedangkan pada saat yang sama penduduk sangat membutuhkan barangbarang tersebut, mereka diharuskan menjual pada tingkat yang setara. ${ }^{13}$

Dalam rangka melindungi hak pembeli dan penjual, Islam membolehkan bahkan mewajibkan melakukan intervensi harga. Ada beberapa faktor yang membolehkan intervensi harga lain: ${ }^{14}$

1. Intervensi harga menyangkut kepentingan masyarakat yaitu melindungi penjual dalam hal Profit Margin (keuntungan), dan pembeli dalam hal purchasing power (kemampuan membeli). Jika harga tidak ditetapkan ketika penjual menjual dengan harga tinggi yang dapat merugikan pembeli.

2. Intervensi Harga mencegah terjadinya ikhtikar (penimbunan).

\footnotetext{
12 Syaik al-Islam Taqiyuddin Ibn Taimiyah, al-Hisbah fi al-Islam,(Riyadh:Mansyurat al-Muassasah al-Sa'idiyyah), h.39

${ }^{13}$ Syaik al-Islam Taqiyuddin Ibn Taimiyah, al-Hisbah ..., h.39

14 Rozalinda, Ekonomi Islam Teori dan Aplikasinya pada Aktivitas Ekonomi,(Jakarta: Rajawali Pers, 2014), h.168-169
} 
3. Intervensi harga melindungi kepentingan masyarakat yang lebih luas karena pembeli biasanya mewakili masyarakat yang lebih luas, sedangkan penjual mewakili kelompok yang lebih kecil.

Suatu intervensi harga dianggap zalim apabila harga maksimum (ceiling price) ditetapkan dibawah harga keseimbangan (Price Equilibrium) ataupun harga minimum yang ditetapkan diatas harga keseimbangan.

Keseimbangan atau equilibrium adalah situasi dimana semua kekuatan yang ada dipasar, penawaran dan permintaan berada dalam keadaan seimbang. Dalam keadaan ini harga dan jumlah barang yang diminta akan sama dengan jumlah barang yang ditawarkan. Proses terjadinya keseimbangan dalam pasar dapat berawal dari sisi mana saja, baik dari permintaan mauoun penawaran. Misalnya permintaan tinggi akan barang kebutuhan dapat menyebabkan pasokan berkurang dan terjadi kelangkaan. Hal ini akan mengakibatkan harga barang meningkat. Sebaliknya jika pasokan barang berlebih maka harga akan cenderung turun. Hal ini akan menyebabkan permintaan konsumen meningkat.

Realitanya keadaan pasar saat ini lebih besar dibawah pengaruh paham kapitalisme, yang mana paham ini meyakini bahwasanya pemilik modal-lah yang menguasai pasar yang bebas menjalankan usahanya demi untuk memperoleh keuntungan yang sebesar-besarnya. Dalam hal ini pemerintah tidak dapat melakukan intervensi pasar guna keuntungan bersama. Pemerintah hanya bertugas menjadi pengawas dari semua pekerjaan yang dilakukan oleh rakyatnya.

Konsep Islam sendiri menegaskan bahwa pasar harus berdiri di atas prinsip persaingan bebas (perfect competition). Namun demikian bukan berarti kebebasan tersebut berlaku mutlak, akan tetapi kebebasan yang dibungkus oleh syari'ah. Dalam Islam, transaksi terjadi secara sukarela (mutual goodwill), sebagaimana disebutkan dalam hadits riwayat Abu Dawud, at-Turmudzi, dan Ibnu Majjah dan asy-Syaukani sebagai berikut: 
Orang-orang berkata: "Wahai Rasulullah, harga mulai mahal. Patoklah harga untuk kami!" Rasulullah SAW bersabda, "Sesungguhnya Allah-lah yang mematok harga, yang menyempitkan dan yang melapangkan rizki, dan aku sungguh berharap untuk bertemu Allah dalam kondisi tidak seorangpun dari kalian yang menuntut kepadaku dengan suatu kezhaliman-pun dalam darah dan harta."

Sejarah telah berulang kali membuktikan bahwa pasar persaingan bebas yang benar-benar membebaskan manusia dengan sebebas-bebasnya yang tidak dilandasi aturan sya'riah tidak mendatangkan keteraturan, melainkan mendatangkan ketidakadilan, krisis yang berulang-ulang, dan kesenjangan sosial yang semakin tinggi, dimana kaum kapital (pemegang modal) semakin kaya, sedangkan mereka yang tak bermodal, semakin terpuruk.

Islam tidak melarang adanya keuntungan dari harga yang ditetapkan oleh produsen, asalkan harga yang ditetapkan tetap berjalan dalam koridor yang telah digambarkan dalam alqur'an maupun hadist, dan persaingan yang terjadi dipasar dilakukan dengan cara-cara yang adil. Kegiatan-kegiatan dipasar yang bisa menimbulkan ketidakadilan tentu saja dilarang dalam Islam, seperti :

1. Talaqqi rukban dilarang karena pedagang yang menyongsong di pinggir kota mendapat keuntungan dari ketidaktahuan penjual dari kampung akan harga yang berlaku di kota.

2. Mengurangi timbangan dilarang, karena barang dijual dengan harga yang sama untuk jumlah yang lebih sedikit.

3. Menyembunyikan barang yang cacat dilarang, karena penjual mendapat harga yang baik untuk kualitas yang buruk.

4. Menukar kurma kering dengan kurma basah dilarang, karena takaran kurma basah ketika kering bisa jadi tidak sama dengan kurma kering yang ditukar. 
5. Menukar satu takar kurma kualitas bagus dengan dua takar kurma kualitas sedang dilarang, karena kualitas kurma mempunyai harga pasarnya.

6. Transaksi najasy dilarang, karena si penjual menyuruh orang lain memuji barangnya atau menawar dengan harga tinggi agar orang lain tertarik.

7. Ikhtikar dilarang, yaitu mengambil keuntungan di atas keuntungan normal dengan menjual lebih sedikit barang untuk harga yang lebih tinggi.

8. Ghaban faa-hisy (besar) dilarang, yaitu menjual di atas harga pasar.

Bahkan Dalam Islam seorang Produsen (pedagang) yang jujur yang senantiasa melandasi bisnis dan perniagaanya dengan niat yang baik dan ikhlas karena Allah, kelak diakhirat akan di samakan kedudukannya dengan para Nabi, shiddiqun dan para syuhada.

Sabda Rasulullah SAW yang diriwayatkan oleh Tirmidzi :

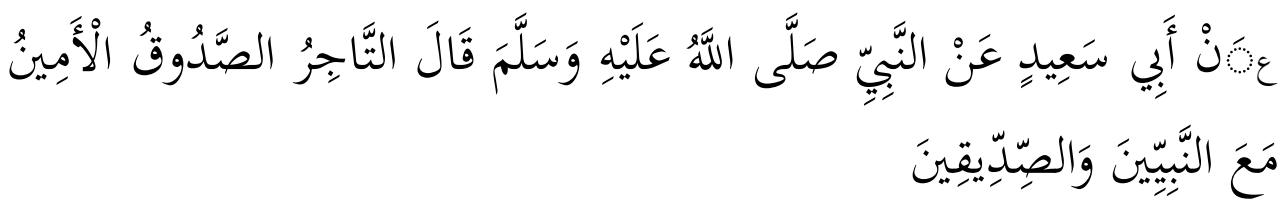

Terjemah :

Abu Sa'id dari Nabi shallallahu 'alaihi wasallam, beliau bersabda: "Seorang pedagang yang jujur dan dipercaya akan bersama dengan para Nabi, shiddiqun dan para syuhada'."

\section{Penutup}

Pemikiran tentang teori harga dalam mekanisme pasar, sejak beriburibu tahun yang lalu telah menjadi perhatian para ulama klasik seperti: Abu Yusuf dan Ibn Khaldun. Pandangan Abu Yusuf diatas dimaksudkan bahwa tidak ada batasan tertentu tentang murah dan mahalnya harga dipasar. Murah bukan karena melimpahnya makanan, demikian juga mahal bukan 
karena kelangkaan makanan, kadang makanan sangat sedikit tetapi harganya murah. Ibn Khaldun mengindikasikan bahwa ketika barang-barang kebutuhan ketersediannya sedikit, maka harga akan naik. Namun, jika terjadi impor barang kebutuhan tersebut, sehingga ketersediannya melimpah maka harga akan turun.

Konsep Islam memahami bahwa pasar bisa berperan aktif dalam kehidupan ekonomi apabila prinsip persaingan bebas bisa diberlakukan secara efektif. Pasar tidak mengharapkan adanya campurtangan dari pihak manapun termasuk Negara dalam hal harga maupun private sector dengan kegiatan monopolistic dan lainnya. Karena pada hakikatnya pasar tidak membutuhkan kekuasaan yang besar untuk menentukan apa yang dikonsumsi dan diproduksi. Dalam keadaan yang darurat diyakini bahwa campurtangan terhadap pasar dapat dilakukan. Yang dimaksud dengan Keadaan darurat di sini adalah jika pasar tidak terjadi dalam keadaan sempurna, dimana terdapat kondisi-kondisi yang menghalangi kompetisi secara adil. 


\section{Daftar Pustaka}

Adiwarman Karim. Sejarah Pemikiran Ekonomi Islam. Jakarta: Rajawali Pers, 2016

Al-Ghazali. Abu Hamid, Ihya' Ulum alDin. Beirut: Dar al Nadwah, n.d. vol 3

Anto, Pengantar Ekonomi Mikro Islam. Yogyakarta: Ekonosia, 2003

Ascarya, Akad dan Produk Bank Syariah. Jakarta: PT RajaGrafindo Persada, 2008

Hafidhudhin. D, Islam Aplikatif. Jakarta: Gema Insani Press, 2003

Ibn Taimiyah, Majmu' Fatawa Shaikh Al IslamAhmad Ibn Taimiyah. Riyadh: al Riyadh Press, 1381 AH. Vol. 8

Irawan, B. S, Manajemen Pemasaran Modern, Edisi Kedua ed. Yogyakarta: Liberty, 2005

Muhammad, Ekonomi Mikro dalam Perspektif Islam. Yogyakarta: BPFE, 2004

Of Rosanthal. Franz, The Muqaddimah of Ibn Khaldun. New York: Princeton University Press, 1967

Misanan, Murokhim, dkk., Ekonomi Islam. Jakarta: Rajagrafindo Persada, 2009

Qardhawi. Y, Norma dan Etika Ekonomi Islam. Jakarta: Gema Insani, 1997

Rozalinda, Ekonomi Islam Teori dan Aplikasinya pada Aktivitas Ekonomi. Jakarta: PT RajaGrafindo Persada, 2014

Saladin, D, Manajemen Pemasaran: Analisis, Perencanaan, Pelaksanaan, dan Pengendalian. Bandung: Linda Karya, 2005

Siddiqi. Muhammad Nejatullah, Economic Thinking of Abu Yusuf, dalam Fikr o Nazar (Aligath), vol. 5. No 1. January 1964

Sudarsono. H, Konsep Ekonomi Islam (Suatu Pengantar). Yogyakarta: Ekonosia, 2004

Winarno, Sigit, Sujana Ismaya, Kamus Besar Ekonomi. Bandung: Pustaka Grafika, 2003

Yunus, Mahmud, Kamus Arab-Indonesia. Jakarta: PT. Hidakarya Agung, 1989 